\title{
THE EFFECT OF MANURING WITH UNDERSOWN WHITE MELILOT ON THE CONTENT OF MICROELEMENTS IN THE TUBERS OF POTATO CULTIVATED IN VARIOUS PRODUCTION SYSTEMS
}

\author{
PŁAZA, A. - GĄSIOROWSKA, B. - RZĄŻEWSKA, E.* - CYBUlSKA, A. - GÓRSKI, R. \\ Agrotechnology Department, Faculty of Natural Sciences, Siedlce University of Natural \\ Sciences and Humanities, Poland \\ (e-mail:anna.plaza@uph.edu.pl; barbara.gasiorowska@uph.edu.pl; \\ anna.cybulska@uph.edu.pl; szur@uph.edu.pl) \\ *Corresponding author \\ e-mail: emilia.rzazewska@uph.edu.pl \\ (Received 27 $7^{\text {th }}$ Mar 2018; accepted $12^{\text {th }}$ Jun 2018)
}

\begin{abstract}
The work presents results of studies conducted from 2008 to 2011 to determine the effect of undersown catch crops, which were either autumn-incorporated or left on the soil surface as mulch for spring incorporation, on the content microelements in potato tubers cultivated in various production systems. The following two factors were examined: I. - manuring with an undersown catch crop: control, farmyard manure, white melilot, white melilot + westerwolds ryegrass, westerwolds ryegrass, white melilot applied as mulch, white melilot + westerwolds ryegrass applied as mulch, westerwolds ryegrass applied as mulch; II. production system: integrated and organic. Potato tuber samples were taken to determine microelements. The results demonstrated that manuring of potato with undersown catch crops, in particular autumnincorporated white melilot, increased iron, zinc and boron contents, and reduced copper and manganese contents in potato tubers. Potatoes cultivated in the integrated production system had a higher concentration of copper, manganese and zinc whereas organic tubers had more iron and boron.
\end{abstract}

Keywords: root crop, green manure, mulch, integrated cultivation, organic cultivation, minerals

\section{Introduction}

Potato is undoubtedly one of our most valuable crop plants and farmyard manure is the basic natural manure applied in potato cultivation. As farmyard manure production has been declining due to a decreasing number of livestock and the development of integrated and organic potato growing, alternative solutions are being sought. In these circumstances, green manures are increasing in popularity (Redulla et al., 2005; Rożyło and Pałys, 2009; Płaza et al., 2015), and undersown catch crops seem to be the cheapest source of organic matter (Płaza et al., 2017). It has been observed that they beneficially affect yields and chemical composition of potato tubers (Różyło and Pałys, 2009; Wierzbicka and Trawczyński, 2011; Płaza et al., 2017). The nutritional value of potato tubers is also determined by minerals, including micronutrients, which after digestion and absorption into the blood are used by the body as a building material or a factor regulating life processes (Wszelaki et al., 2005). In order for the human body to function properly, it must receive from the outside all the necessary micronutrients, especially iron, zinc, boron, copper and manganese. However, there is a paucity of Polish studies on the influence of undersown white melilot on the potato tuber content of microelements. Consumers expect potato producers, in particular organic potato growers, to provide more nutritious tubers, but there is still little research comparing the chemical composition of potato tubers produced in various production systems. Hence, 
the need arises to conduct this type of research. The purpose of the study reported here was to determine the effect of undersown catch crops, which were either autumnincorporated or left as mulch on the soil surface for spring incorporation, on the content of microelements in the tubers of potato grown in various production systems.

\section{Materials and methods}

A field experiment was carried out at the Zawady Experimental Farm $\left(50^{\circ} 20^{\prime} \mathrm{N}\right.$, $22^{\circ} 30^{\prime}$ E) which belongs to Siedlce University of Natural Sciences and Humanities, Poland in 2008-2011. The experimental soil was Albic Luvisol (Arenic), soil valuation class IVa. The soil contents of available minerals were as follows: P $5.29 \mathrm{mgkg}^{-1}, \mathrm{~K}$ $11.59 \mathrm{mgkg}^{-1}, \mathrm{Mg} 5.60 \mathrm{mgkg}^{-1}, \mathrm{Mn} 114 \mathrm{mgkg}^{-1}, \mathrm{Cu} 1.8 \mathrm{mgkg}^{-1}, \mathrm{~B} 0.54 \mathrm{mgkg}^{-1}, \mathrm{Zn} 7.5$ $\mathrm{mgkg}^{-1}, \mathrm{Fe} 654 \mathrm{mgkg}^{-1}$. Soil reaction was neutral and humus content amounted to $1.37 \%$. The experiment was a split-block arrangement with three replicates. The following two factors were examined: I. - manuring with an undersown catch crop: control (no undersown catch crop manure), farmyard manure $\left(30\right.$ tha $\left.^{-1}\right)$, Melilotus albus (seed sowing rate $26 \mathrm{kgha}^{-1}$ ), Melilotus albus + Lolium westerwoldicum (seed sowing rate $13+10 \mathrm{kgha}^{-1}$ ), Lolium westerwoldicum (seed sowing rate $20 \mathrm{kgha}^{-1}$ ), Melilotus albus applied as mulch (seed sowing rate $26 \mathrm{kgha}^{-1}$ ), Melilotus albus + Lolium westerwoldicum applied as mulch (seed sowing rate $13+10 \mathrm{kgha}^{-1}$ ), Lolium westerwoldicum applied as mulch (seed sowing rate $20 \mathrm{kgha}^{-1}$ ); II. - production system: integrated and organic.

In autumn, fresh matter yield of undersown catch crops, including their root mass to the depth of $30 \mathrm{~cm}$, was determined in a $1 \mathrm{~m}^{2}$ area in each plot. The average yields calculated across three years in the integrated and organic production systems were, respectively, 27.5 and 22.9 tha $^{-1}$ for Melilotus albus, 31.7 and 25.8 tha $^{-1}$ for Melilotus albus + Lolium westerwoldicum, and 35.4 and 27.6 tha $^{-1}$ for Lolium westerwoldicum.

Table potato was preceded by spring triticale grown for grain which was undersown with catch crops. In the integrated production system, mineral fertilisers were applied to the whole experimental area in early spring. Their rates per 1 ha were as follows: $90 \mathrm{~kg} \mathrm{~N}$, $36.9 \mathrm{~kg} \mathrm{P}$ and $99.6 \mathrm{~kg} \mathrm{~K}$. The rates were adjusted to soil availability and projected yield levels. In autumn-ploughed plots, mineral fertilisers were spread in the spring and mixed with the soil by means of a cultivator with a harrow attached to it. In mulched plots, a disc harrow was followed by a cultivator. In the organic system, instead of mineral fertilisers farmyard manure was applied at the rate of $30 \mathrm{tha}^{-1}$ to the whole experimental area, and followed by spring triticale which was undersown with catch crops. Potatoes were planted in late April and harvested in mid-September. In the integrated production system, weeds, pests and diseases were controlled using mechanical practices and chemicals. Prior to emergence, potatoes were hilled and harrowed every 7 days, and just before emergence, they were sprayed with a mixture of the herbicides Afalon $50 \mathrm{WP}+$ Reglone Turbo 200 SL $\left(1 \mathrm{~kg}+1 \mathrm{dm}^{3} \mathrm{ha}^{-1}\right)$. Colorado potato beetle and late blight were controlled by means of two applications of, respectively, the pesticide Fastac $\left(0.1 \mathrm{dm}^{3} \mathrm{ha}^{-1}\right)$ and the fungicide Ridomil MZ WP $\left(2 \mathrm{dm}^{3} \mathrm{ha}^{-1}\right)$. Organic potatoes were mechanically protected against weeds. Colorado potato beetle was controlled using two applications of Novodor SC (2.5 $\left.\mathrm{dm}^{3} \mathrm{ha}^{-1}\right)$, and Miedzian $50 \mathrm{WP}\left(4 \mathrm{kgha}^{-1}\right)$ was applied three times to keep late blight in check. During potato harvest, after 10 tuber samples were collected in each plot to analyse for microelements. $\mathrm{Cu}, \mathrm{Fe}, \mathrm{Mn}, \mathrm{Zn}$ and $\mathrm{B}$ contents were determined in the dry matter of potato tubers by means of the Inductively Coupled Plasma Optical Emission 
Spectrometry (ICP-OES) at wavelength: $\mathrm{Cu} 327.393$ nm, Fe 238.204 nm, Mn 257.601 $\mathrm{nm}, \mathrm{Zn} 206.200 \mathrm{~nm}, \mathrm{~B} 249.677 \mathrm{~nm}$.

Data obtained for each of the characteristics studied was analysed by means of ANOVA suitable for the split-block mathematical model, according to the model: yijl = $\mathrm{n}+\mathrm{ai}+\mathrm{gj}+\mathrm{eij}(1)+\mathrm{bl}+\mathrm{ejl}(2)+$ abil + eijl (3), where $\mathrm{a}=1.2 ; \mathrm{b}=1,2 . .8 ; \mathrm{n}=1,2,3$ (number of repetitions); yijl - value of the examined feature; ai - the effect of the i-th factor A; gj - the effect of repetitions (blocks); eij (1) - error 1 resulting from factor A interaction and repetition; bl - the effect of the $1^{\text {st }}$ level factor $B$; ejl (2) - error 2 resulting from interaction factor $B$ and repetitions; abil - effect of factor interaction $A$ and B; eijl (3) - random error. When significant sources of variation were detected, Tukey test was applied to separate the means.

\section{Results}

\section{The copper content of potato tuber}

Copper content in potato tubers was significantly affected by the experimental factors and their interaction (Table 1). The highest copper content was recorded in the tubers of control potato. An application of farmyard manure and undersown catch crops contributed to a significant decline in the potato tuber content of copper. The highest content was recorded in the tubers of potato following autumn-incorporated white melilot. Also production system had a significant effect on the concentration of copper in potato tubers, it being higher in the tubers of potato grown using integrated farming practices than in organic tubers. An interaction between the experimental factors was confirmed. It indicated that the highest copper content was found in the tubers of control potato following mineral fertiliser only, in the integrated production system, and the lowest concentration was determined in the tubers of organic potato following farmyard manure and undersown catch crops.

Table 1. Copper content in potato tubers depending on the manuring with undersown catch crop and production system (means over 2009-2011), $\mathrm{mgkg}^{-1} \mathrm{~d} . \mathrm{m}$.

\begin{tabular}{c|c|c|c}
\hline \multirow{2}{*}{ Manuring with undersown catch crop } & \multicolumn{2}{|c|}{ Production system } & \multirow{2}{*}{ Means } \\
\cline { 2 - 3 } & Integrated & Organic & \\
\hline Control & 5.085 & 4.763 & 4.924 \\
Farmyard manure & 4.850 & 4.635 & 4.743 \\
White melilot & 4.737 & 4.554 & 4.646 \\
White melilot + westerwolds ryegrass & 4.794 & 4.605 & 4.699 \\
Westerwolds ryegrass & 4.839 & 4.613 & 4.726 \\
White melilot - mulch & 4.743 & 4.601 & 4.672 \\
White melilot + westerwolds ryegrass - mulch & 4.801 & 4.617 & 4.709 \\
Westerwolds ryegrass - mulch & 4.848 & 4.622 & 4.735 \\
\hline Means & 4.837 & 4.626 & - \\
\hline ANOVA & \multicolumn{2}{|c}{ P-value } & LSD $_{0.05}$ \\
\hline Manuring with undersown catch crop & $<0.001$ & 0.077 \\
\hline Production system & \multicolumn{2}{|c}{0.001} & 0.071 \\
\hline Interaction & \multicolumn{2}{c}{0.095} \\
\hline
\end{tabular}




\section{The iron content of potato tuber}

Statistical analysis revealed a significant influence of the experimental factors and their interaction on iron content in potato tubers (Table 2). The lowest iron content was recorded in the tubers of potato harvested in the control unit. A application of farmyard manure and undersown catch crops resulted in a significant increase in the potato tuber content of iron. The highest concentration of this element was recorded in the tubers of potato following spring-incorporated white melilot. Iron content in the tubers of potato manured with an autumn-incorporated mixture of white melilot and westerwolds ryegrass, and white melilot left as mulch on the soil surface for spring incorporation differ insignificantly from the concentration of iron in the tubers of potato following farmyard manure. In the remaining plots, iron content was lower compared with farmyard manure. Production system significantly affected iron content in potato tubers, it being higher in the tubers of organic potato. An interaction between the experimental factors was confirmed, which demonstrated that the highest iron content was recorded in the tubers of potato manured with autumn-incorporated white melilot in the integrated and organic potato system, it being the lowest in the tubers of control potato, following mineral fertilisers only, in the integrated production system.

Table 2. Iron content in potato tubers depending on the manuring with undersown catch crop and production system (means over 2009-2011), $\mathrm{mgkg}^{-1}$ d.m.

\begin{tabular}{|c|c|c|c|}
\hline \multirow{2}{*}{ Manuring with undersown catch crop } & \multicolumn{2}{|c|}{ Production system } & \multirow{2}{*}{ Means } \\
\hline & Integrated & Organic & \\
\hline Control & 43.39 & 45.44 & 44.42 \\
\hline Farmyard manure & 51.80 & 53.24 & 52.52 \\
\hline White melilot & 54.86 & 56.01 & 55.44 \\
\hline White melilot + westerwolds ryegrass & 50.77 & 51.84 & 51.31 \\
\hline Westerwolds ryegrass & 46.44 & 47.52 & 46.98 \\
\hline White melilot - mulch & 51.33 & 53.40 & 52.37 \\
\hline White melilot + westerwolds ryegrass - mulch & 49.48 & 50.56 & 50.02 \\
\hline Westerwolds ryegrass - mulch & 45.39 & 46.81 & 46.10 \\
\hline Means & 49.18 & 50.60 & - \\
\hline ANOVA & \multicolumn{2}{|c|}{ P-value } & $\mathrm{LSD}_{0.05}$ \\
\hline Manuring with undersown catch crop & \multicolumn{2}{|c|}{$<0.001$} & 1.29 \\
\hline Production system & \multicolumn{2}{|c|}{$<0.001$} & 0.83 \\
\hline Interaction & \multicolumn{2}{|c|}{0.001} & 1.43 \\
\hline
\end{tabular}

\section{The manganese content of potato tuber}

Manganese content in potato tubers was significantly affected by the experimental factors and their interaction (Table 3). The lowest concentration of manganese was determined in the tubers of control potato. An application of farmyard manure and undersown catch crops contributed to a significant decline in the potato tuber content of manganese. The lowest concentration of this element was recorded in the tubers of potato following undersown catch crops, whether they had been ploughed down in autumn or left as mulch on the soil surface for spring incorporation. Production system 


$$
-5075 \text { - }
$$

had a significant influence on the potato tuber content of manganese, it being higher in the tubers of potato grown in the integrated versus organic production system. An interaction between the experimental factors was confirmed. It explains why the highest manganese content was found in the tubers of control potato, which followed mineral fertiliser only, in the integrated production system, and the lowest concentration was determined in the tubers of organic potato manured with Melilotus albus, regardless of when the undersown catch crop had been incorporated.

Table 3. Manganese content in potato tuber depending on the manuring with undersown catch crop and production system (means over 2009-2011), $\mathrm{mgkg}^{-1}$ d.m.

\begin{tabular}{|c|c|c|c|}
\hline \multirow{2}{*}{ Manuring with undersown catch crop } & \multicolumn{2}{|c|}{ Production system } & \multirow{2}{*}{ Means } \\
\hline & Integrated & Organic & \\
\hline Control & 8.868 & 8.635 & 8.752 \\
\hline Farmyard manure & 8.653 & 8.466 & 8.559 \\
\hline White melilot & 8.260 & 8.135 & 8.198 \\
\hline White melilot + westerwolds ryegrass & 8.361 & 8.244 & 8.303 \\
\hline Westerwolds ryegrass & 8.448 & 8.341 & 8.395 \\
\hline White melilot - mulch & 8.319 & 8.204 & 8.365 \\
\hline White melilot + westerwolds ryegrass - mulch & 8.411 & 8.318 & 8.365 \\
\hline Westerwolds ryegrass - mulch & 8.508 & 8.410 & 8.459 \\
\hline Means & 8.479 & 8.344 & - \\
\hline ANOVA & \multicolumn{2}{|c|}{ P-value } & $\mathrm{LSD}_{0.05}$ \\
\hline Manuring with undersown catch crop & \multicolumn{2}{|c|}{$<0.001$} & 0.084 \\
\hline Production system & \multicolumn{2}{|c|}{$<0.001$} & 0.079 \\
\hline Interaction & \multicolumn{2}{|c|}{0.001} & 0.095 \\
\hline
\end{tabular}

\section{The zinc content of potato tuber}

Statistical analysis demonstrated a significant effect of the factors examined in the experiment and their interaction on zinc content in potato tubers (Table 4).

Table 4. Zinc content in potato tuber depending on the manuring with undersown catch crop and production system (means over 2009-2011), $\mathrm{mgkg}^{-1} \mathrm{~d} . \mathrm{m}$.

\begin{tabular}{c|c|c|c}
\hline \multirow{2}{*}{ Manuring with undersown catch crop } & \multicolumn{2}{|c|}{ Production system } & \multirow{2}{*}{ Means } \\
\cline { 2 - 3 } & Integrated & Organic & 11.29 \\
Control & 11.71 & 10.87 & 12.90 \\
Farmyard manure & 13.33 & 12.46 & 13.90 \\
White melilot & 14.66 & 13.13 & 13.42 \\
White melilot + westerwolds ryegrass & 13.88 & 12.95 & 12.85 \\
Westerwolds ryegrass & 13.03 & 12.66 & 13.56 \\
White melilot - mulch & 13.91 & 13.20 & 12.97 \\
White melilot + westerwolds ryegrass - mulch & 13.39 & 12.55 & 12.41 \\
Westerwolds ryegrass - mulch & 12.80 & 12.02 & - \\
\hline Means & 13.34 & 12.48 & LSD $_{0.05}$ \\
\hline ANOVA & \multicolumn{2}{|c}{ P-value } & 0.69 \\
\hline Manuring with undersown catch crop & $<0.001$ & 0.50 \\
\hline Production system & \multicolumn{2}{c}{0.001} \\
\hline Interaction & \multicolumn{2}{|}{} & 0.91 \\
\hline
\end{tabular}


The highest zinc content was recorded in the tubers of potato harvested in the control unit. An application of farmyard manure and undersown catch crops resulted in an increase in the concentration of zinc in potato tubers. The highest zinc content was determined in the tubers following autumn-incorporated white melilot. There were no significant differences between the zinc contents in the tubers of potato following farmyard manure and the remaining undersown catch crops. Production system significantly affected the potato tuber content of zinc, too. The concentration of this element was higher in the tubers of potato cultivated using integrated farming practices rather than organic management. An interaction between the experimental factors was confirmed. It explained why the highest zinc content was recorded in the tubers of potato manured with autumn-incorporated Melilotus albus and a mixture of Melilotus albus and Lolium westerwoldicum in the integrated production system, and the lowest concentration of zinc was in control tubers grown in both the production system.

\section{The boron content of potato tuber}

Boron content in potato tubers was significantly affected by the experimental factors and their interaction (Table 5).

Table 5. Boron content in potato tuber depending on the manuring with undersown catch crop and production system (means over 2009-2011), $\mathrm{mgkg}^{-1}$ d.m.

\begin{tabular}{c|c|c|c}
\hline \multirow{2}{*}{ Manuring with undersown catch crop } & \multicolumn{2}{|c|}{ Production system } & \multirow{2}{*}{ Means } \\
\cline { 2 - 3 } & Integrated & Organic & \\
\hline Control & 4.635 & 4.744 & 4.689 \\
Farmyard manure & 5.337 & 5.473 & 5.405 \\
White melilot & 5.631 & 5.837 & 5.734 \\
White melilot + westerwolds ryegrass & 5.395 & 5.578 & 5.487 \\
Westerwolds ryegrass & 5.131 & 5.297 & 5.214 \\
White melilot - mulch & 5.546 & 5.701 & 5.624 \\
White melilot + westerwolds ryegrass - mulch & 5.293 & 5.442 & 5.368 \\
Westerwolds ryegrass - mulch & 5.029 & 5.170 & 5.099 \\
\hline Means & 5.250 & 5.405 & - \\
\hline ANOVA & \multicolumn{2}{|c|}{ P-value } & LSD $_{0.05}$ \\
\hline Manuring with undersown catch crop & $<0.001$ & 0.063 \\
\hline Production system & \multicolumn{2}{c}{0.001} \\
\hline Interaction & \multicolumn{2}{c}{0.044} \\
\hline
\end{tabular}

The lowest boron content was found in the tubers of control potato. An application of farmyard manure and undersown catch crops contributed to an increase in the potato tuber content of boron. The highest concentration of this element was recorded in the tubers of potato grown in plots amended with Melilotus albus, whether it was autumnincorporated or left as mulch on the soil surface for spring incorporation. Boron content in the tubers of potato following a mixture of Melilotus albus and Lolium westerwoldicum differ insignificantly from the value recorded determined in the tubers harvested in farmyard manure-amended plots. In the remaining units manured with undersown catch crops, boron content in potato tubers was significantly lower compared with the tubers of potato following farmyard manure. Production system had 
a significant impact on the potato tuber content of boron. The concentration of this element was higher in the tubers of organic potato compared with the integrated production system. There was a confirmed interaction between the experimental factors which provided an explanation why the highest boron content was recorded in the tubers of organic potato following autumn-incorporated Melilotus albus, and the lowest concentration was determined in control tubers, following mineral fertiliser only, in the integrated production system.

\section{Discussion}

Microelements are as important as macroelements. However, their content in potato tubers is much lower. They are components of enzymes which activate a range of biochemical processes (Różyło and Pałys, 2009; Wierzbicka and Trawczyński, 2011; Wierzbicka, 2012).

In this study, the highest copper content was determined in control tubers which were harvested in plots where only mineral fertilisers had been applied. Also Klikocka (2009) as well as Braun et al. (2011) obtained a higher copper content in the tubers of potato following mineral fertiliser. In the experiment reported here, an application of farmyard manure and undersown catch crops prior to potato cultivation contributed to a significant decline in the tuber content of copper. Trawczyński and Bogdanowicz (2007), Wierzbicka and Trawczyński (2011), Wierzbicka (2012) and Osvalde et al. (2016) found that vermicompost and green manures reduced copper content in potato tubers. Wierzbicka and Trawczyński (2011) in organic potato cultivation with the use of stubble catch crops with white mustard, field pea and serradella in irrigation conditions showed a decrease in copper content in tubers. This is in line with the results of the Wierzbicka study (2012), which investigated the copper content in potato tubers of cultivated also in the organic production system of manured with stubble catch crops without irrigation. However, in the discussed experiment a different form of green manure was used, undersown catch crop, both plowed in autumn and left to spring in the form of mulch, which in Polish conditions has not been studied so far. It was shown that manuring the potato with Melilotus albus also caused a decrease in copper content in tubers. The experiment was carried out in two production systems, not only in organic one, as in the studies of Wierzbicka and Trawczyński (2011) or Wierzbicka (2012).

Similarly to Hajšlovă et al. (2005) Wang et al. (2008), Hunter et al. (2011) and Sawicka et al. (2016), in the present study, copper content was lower in organic potato tubers.

In the experiment reported here, the lowest iron content was determined in control tubers, which supports findings reported by Braun et al. (2011), Hadi et al. (2014) and Ashafzadeh et al. (2017) who demonstrated that iron content was the lowest in the tubers of potatoes following mineral fertiliser only. In the current study, farmyard manure and undersown catch crops contributed to an increase in the potato tuber content of iron. It follows from the fact that farmyard manure and green manures introduce additional amounts of macroelements and microelements into the soil (Wierzbicka and Trawczyński, 2011; Płaza et al., 2017). In the experiment discussed here, tubers of organic potato following green manures and farmyard manure contained significantly more iron compared with the integrated system. Such a relationship was also observed 
in the studies by Wiśniowska-Kieljan and Klima (2007), Wierzbicka (2012) and Sawicka et al. (2016).

In the present study, the highest manganese content was determined in the tubers of control potato following mineral fertiliser only. Similar findings were reported by White et al. (2009), Braun et al. (2011), Hadi et al. (2014) and Baranowska et al. (2017). Undersown catch crops and farmyard manure applied in the experiment reported here contributed to a significant decline in the potato tuber content of manganese, which corresponds with results obtained by Redulla et al. (2005) as well as Różyła and Pałys (2009). Also Baranowska et al. (2017) demonstrated that soil conditioner application was associated with a decline in manganese content in potato tubers. In the present work, a higher manganese content was determined in the tubers of potato cultivated in the integrated versus organic production system, the finding being similar to results reported by Wszelaki et al. (2005) and Sawicka et al. (2016).

In the trial discussed here, the lowest zinc content was determined in the tubers of control potato. Also Braun et al. (2011), Hadi et al. (2014) and Ashrafzadeh et al. (2017) found the lowest concentration of zinc in the tubers of potato following mineral fertiliser. In the present study, farmyard manure and undersown catch crops, which provide potato plants with macroelements and microelements, contributed to an increase in the potato content of zinc. Trawczyński and Bogdanowicz (2007), Różyło and Pałys (2009), White et al. (2009) as well as Wierzbicka and Trawczyński (2011) have demonstrated that green manures increase zinc content in potato tubers. In this study, zinc content was higher in the tubers of potato grown in the integrated versus organic production system. A similar relationship was found by Hajšlovă et al. (2005), Wang et al. (2008) and Sawicka et al. (2016).

In the present work, control potatoes contained the lowest amounts of boron, which agrees with reports by Sayed et al. (2015) and Osvalde et al. (2016). Farmyard manure and undersown catch crops contributed to an increase in the potato tuber content of boron. Also Wierzbicka and Trawczyński (2011) as well as Osvalde et al. (2016) observed that green manures and vermicompost increased the concentration of boron in potato tubers. In the present study as well as in the works by Hajšlovă et al. (2005), Wierzbicka and Trawczyński (2011) and Wierzbicka (2012), a higher boron content was recorded in the tubers of organic potato.

In the conducted study, it was discovered that potato manuring with the form Melilotus albus, both plowed in autumn and left to the spring in the form of mulch, most preferably affects the content of micronutrients in tubers. Increases the content of iron, zinc and boron in potato tubers, and decreases the content of copper and manganese. Potato from the organic production system contained more iron and boron, and from the integrated production system more copper, manganese and zinc, which indicates a more favorable content of micronutrients in tubers from the organic production system.

\section{Conclusions}

1. Potato manuring with undersown catch crops, and especially with the little clover plowed in autumn, increases the content of zinc and boron iron in potato tubers, and reduces the content of copper and manganese (micronutrients of lesser nutritional importance). 
2. Potatoes cultivated in the integrated production system were characterized by a higher concentration of copper, manganese and zinc, and cultivated in the organic production system a higher content of iron and boron.

3. In the conducted research, it was discovered that potato manuring with one year's form of Melilotus albus, both plowed in autumn and left to spring in the form of mulch in an ecological production system, provides the most beneficial micronutrient content in tubers.

\section{REFERENCES}

[1] Ashrafzadeh, S., Gaw, S., Genet, R., Glover, C. N., Leung, D. W. M. (2017): Natural variation in correlations between cadmium and micronutrients in potato tubers. - Journal of Food Composition and Analysis 59: 55-60. DOI: 10.1016/jfca.2017.02.008.

[2] Baranowska, A., Zarzecka, K., Gugała, M., Mystkowska, I. (2017): Contents of zinc, copper and manganese in potato tubers depending on the ways of application of the soil fertilizer UGmax. - Journal of Ecological Engineering 18(1): 99-106. DOI: 10.12911/22998993/66250.

[3] Braun, H., Fontes, P. C. R., Busato, C., Cecon, P. R. (2011): Macro and micronutrient concentration and accumulation in tuber of potato cultivars as affected by nitrogen. Bragandia 70(1): 50-57. DOI: 10.1590/S0006-87052011000100009.

[4] Hadi, M. R., Taheri, R., Balali, G. R. (2014): Effects of iron and zinc fertilizers on the accumulation of $\mathrm{Fe}$ and $\mathrm{Zn}$ ions in potato tubers. - Journal of Plant Nutrition 38(2): 202211. DOI: 10.1080/01904167.2014.934465.

[5] Hajšlovă, J., Schulzovă, V., Slanina, P., Janne, K., Hellenăs, K. E., Andersson, Ch. (2005): Quality of organically and conventionally grown potatoes: four-year study of micronutrients, metals, secondary metabolites, enzymic browning and organoleptic properties. - Food Additives and Contaminants 22(6): 514-534.

[6] Hunter, D., Foster, M., Mcarthu, J. O., Ojha, R., Petocz, P., Samman, S. (2011): Evaluation of the micronutrient composition of plant foods produced by organic and conventional agricultural methods. - Critical Reviews in Food Science and Nutrition 51(6): 571-582.

[7] Klikocka, H. (2009): Influence of NPK fertilization enriched with S, Mg, and micronutrients contained in liquid fertilizer Insol 7 on potato tubers yield (Solanum tuberosum L.) and infestation of tubers with Streptomyces scabies and Rhizoctonia solani. - Journal of Elementology 14(2): 271-288.

[8] Makarewicz, A., Płaza, A., Gąsiorowska, B., Rosa, R., Cybulska, A., Górski, R., Rzążewska, E. (2018): Effect of manuring with undersown catch crops and production system on the potato tuber content of macroelements. - Journal of Elementology 23(1): 719. DOI: 10.5601/jelem.2017.22.1.1398 (in Polish).

[9] Osvalde, A., Karisons, A., Cekstere, G., Vojevode, L. (2016): The effect of vernicompost-derived humic substances on nutrient status and yield of organic potato in field conditions. - Acta Horticulturae 1141: 277-283. DOI: 10.17660/Acta Hortic.2016.1142.42.

[10] Płaza, A., Makarewicz, A., Gąsiorowska, B. (2015): Influence of undersown catch crops on mineral nitrogen content determined in the soil profile in autumn and spring in conventional and organic farming system. - Fresenius Environmental Bulletin 10a(24): 3315-3319.

[11] Płaza, A., Makarewicz, A., Gąsiorowska, B., Cybulska, A., Górski, R., Rzążewska, E. (2017): Macroelement content in potato tubers as affected by manuring with undersown catch crop, and production system. - Electronic Journal of Polish Agricultural Universities, Topic Agronomy 20(4): 16. www.ejpau.media.pl (in Polish). 
[12] Redulla, C. A., Davenport, J. R., Evans, R. G., Hatterndorf, M. J., Alva, A. K., Boydston, R. A. (2005): Relating potato yield and quality to field scale variability in soil characteristics. - American Journal of Potato Research 79(5): 317-323. DOI: 10.1007/bf02870168.

[13] Różyło, K., Pałys, E. (2009): The chemical composition of potato tubers and its correlations with the amount of weed infestation depending on the fertilization system and the agronomical category of soil. - Annales UMCS, Sectio E, Agricultura 44(3): 110119 (in Polish).

[14] Rusinovci, I., Aliu, S., Fetahu, S., Kaciu, S., Salihu, S., Zeka, D., Berisha, D. (2011): Content of mineral substances in the potato (Solanum tuberosum L.) tubers depending on cultivar and locality in the agro-ecological conditions of Kosovo. - Acta Horticulturae 960: 289-292.

[15] Sawicka, B., Barbaś, P., Skiba, D. (2016): Fluctuations of sodium, copper, zinc, iron and manganese in potato tubers in the organic and integrated production system. - Journal of Elementology 21(2): 539-547. DOI: 10.5601/jelem.2015.20.2.865 (in Polish).

[16] Sayed, F., Hassan, A., Mohamed, M. (2015): Impact of bio-and organic fertilizers on potato yield, quality and tuber weight loss after harvest. - Potato Research 58(1): 67-81.

[17] Trawczyński, T., Bogdanowicz, P. (2007): Soil conditioner application in the organic production of potato. - Journal of Research Applications in Agricultural Engineering 57(4): 188-192 (in Polish).

[18] Wang, Z., Li, S., Malhi, S. (2008): Effects of fertilization and other agronomic measures on nutritional quality of crops. - Journal of the Science of Food and Agriculture 88: 7-23.

[19] White, P., Bradshaw, J. E., Dale, M. F. B., Ramsay, G. (2009): Relationship between yield and mineral concentrations in potato tubers. - Horticulturae Science 44(1): 6-11.

[20] Wierzbicka, A. (2012): Mineral content of potato tubers grown in the organic system their nutritional value and interaction. - Journal of Research Applications in Agricultural Engineering 57(4): 188-192 (in Polish).

[21] Wierzbicka, A., Trawczyński, C. (2011): Effect of irrigation and soil's microorganisms on the macro- and micronutrient content in organic potato tubers. - Fragmenta Agronomica 28(4): 139-148 (in Polish).

[22] Wiśniowka-Kieljan, B., Klima, K. (2007): Comparison of microelement content in winter wheat grain from organic and conventional farms. - Journal of Research Applications in Agricultural Engineering 52(4): 100-103 (in Polish).

[23] Wszelaki, A. L., Delwiche, J. F., Walker, S. D., Laggett, R. E., Scheerens, J. C., Kleinhenz, M. D. (2005): Sensory quality and mineral and glycoalkaloid concentrations in organically and conventionally grown redskin potatoes (Solanum tuberosum). Journal of the Science of Food and Agriculture 85(5): 720-726. DOI: 10.1002/jsfa.2051. 